\title{
Assessment of Genetic Diversity, Population Structure and Phytochemical Variations in Polygonatum Cirrhifolium (Wall.) Royle - An Endangered Medicinal Herb
}

\section{Renu Suyal}

GB Pant Institute of Himalayan Environment and Development: Govind Ballabh Pant National Institute of Himalayan Environment and Sustainable Development

Arun K. Jugran ( $\sim$ arunjugran@gmail.com )

Govind Ballabh Pant Institute of Himalayan Environment and Development: Govind Ballabh Pant National Institute of Himalayan Environment and Sustainable Development https://orcid.org/0000-0003-3294-2847

\section{Indra D. Bhatt}

Govind Ballabh Pant Institute of Himalayan Environment and Development: Govind Ballabh Pant National Institute of Himalayan Environment and Sustainable Development

\section{Ranbeer S. Rawal}

Govind Ballabh Pant National Institute of Himalayan Environment and Sustainable Development

\section{Research Article}

Keywords: Polygonatum cirrhifolium, Threatened, Population structure, Antimutagenic activity

Posted Date: December 16th, 2021

DOl: https://doi.org/10.21203/rs.3.rs-1110766/v1

License: (1) (1) This work is licensed under a Creative Commons Attribution 4.0 International License. Read Full License

Version of Record: A version of this preprint was published at Genetic Resources and Crop Evolution on April 13th, 2022. See the published version at https://doi.org/10.1007/s10722-022-01378-7. 


\section{Abstract}

Polygonatum cirrhifolium is an important medicinal herb of family Asparagaceae used to cure several ailments. Its rhizome forms an important ingredient of "Chyavanprash" which is identified for its rejuvenating properties. However, P.cirrhifolium is least explored scientifically and systematically till date. Therefore, in this study genetic diversity and phytochemical variations along with antimutagenic activity of P.cirrhifolium populations was evaluated. Antimutagenic activity varied remarkably $(p<0.05)$ having Gagar population with significantly $(\mathrm{p}<0.05)$ higher DNA recovery $(84.95 \%)$ percentage. Higher genetic diversity $(\mathrm{He})$ was recorded among populations using RAPD ( $\mathrm{He}, 0.30-0.36)$ and ISSR (0.25-0.38) markers. High intra and low inter population variations were recorded in the species using both kinds of markers. Phenolics ( $<<0.05 ; r=0.924)$; tannins $(p<0.05 ; r=0.897)$ and DNA damage inhibition efficiency displayed a highly positive correlation with genetic diversity (estimated using ISSR markers). The population structure analysis of $P$. cirrhifolium revealed that the greatest value of the $\mathrm{K}$ was 3 for studied populations. Gene flow among studied populations was found sufficient to encounter genetic erosion in the species. Therefore, it can be recommended that the populations with higher ingredient and genetic diversity can be utilized for conservation priority and management plan of this species.

\section{Introduction}

Polygonatum Mill. (Asparagaceae) is a genus of perennial herbs, owing to its wide array of health benefits the species of this genus has been used traditionally.. The genus comprises of 71 species of which 37 species are reported for medicinal value (Zhao et al. 2018). Most Polygonatum species comprises global curative properties and hence, consists of positions in Indian Ayurveda, traditional Chinese medicines, different pharmacopoeias, etc. Polygonatum herbs are rich source of diosgenin, polysaccharides, steroidal saponins, homoisoflavanones, etc. (Liu et al. 2011; Khan et al. 2012; Wang et al. 2019) and hence, efficient as cardio-tonic (Hirai et al. 1997), anti-inflammatory (Khan et al. 2013), antispasmodic (Khan et al. 2016), antimutagenic (Suyal et al. 2019a) etc. Most of the important Polygonatum species lacks phytochemical, pharmacological and genetic diversity researches. One such vital herb is Polygonatum cirrhifolium (Wall.) Royle generally recognized as Mahameda. The species is disseminated in the Himalayas from India, Bhutan, Nepal and China, to Pakistan (www.tropicos.org). Diverse plant parts of species like leaf, seeds, and rhizomes are utilized to treat kidney, rheumatism, and dermatological disorders. Rhizomes forms primary raw material of the Astavarga formulation, which is utilized in seminal weakness and as a cure for rakta, vata and pitta doshas (Balakrishna et al. 2012). The rhizome, stems and leaves of $P$. cirrhifolium are rich in bioactive sources such as steroidal saponins, flavonoids, anthraquinones, and their glycosides, coumarins, carbohydrates, etc. In addition, proteins, amino acids and polyphenols are also recorded from roots and lactones in stems and leaves (Wang et al. 2006).

P. cirrhifolium is adapted in several ecological habitats having prevalent variations in environmental conditions which ultimately affect the superiority and efficacy of the ultimate produce (Suyal et al. 2019a). Thus, evaluation of quality resources of P.cirrhifolium is essentially required. According to local and unofficial reports huge amount of plant rhizome is collected annually from the Himalayan area due to species demand in domestic and global market and hence, depleted the species germplasm. Few reports are existing on diversity and distribution (Suyal et al. 2019b), propagation protocols (Latoo et al. 2005) and pharmacological activity (Xu et al. 2017) of P.cirrhifolium. However, none of the studies so far reported the genetic diversity, phytochemical, and anti-mutagenic property of the species. Studies on these aspects are necessary for elite identification and managing the species. Studies of genetic diversity are getting popularity across the world for setting priorities of conservation, especially to introduce the species in its natural habitats. Moreover, only few reports are available on the genetic multiplicity evaluation of herbal species from Himalayan region (Jugran et al. 2013; Giri et al. 2016; Fang et al. 2018; Ray et al. 2019). This signifies an urgent need to quantify the genetic diversity among the populations of threatened and endemic medicinal plants species towards predicting the future persistence. Random amplified polymorphic DNA (RAPD) and Inter simple sequence repeats (ISSR) markers are among such markers that are extensively employed for assessing genetic diversity and population structure studies of several plant species due to their cost effectiveness, robustness and high reproducibility (Fang et al. 2018). However, no prior information is available on the genetic diversity analysis and antimutagenic activity of P.cirrhifolium. Therefore, the major objectives of this investigation is to (i) characterize the genetic structure and differentiation of the studied populations, (ii) examine phytochemical, antioxidant and DNA damage inhibition efficiency of selected populations, and (iii) to establish relationship among phytochemicals, antioxidant properties and molecular attributes.

\section{Material And Methods}

\section{Exploration and collection of plant material}


Extensive field investigation was carried in Kumaun region $\left(28^{\circ} 44^{\prime}\right.$ to $30^{\circ} 49^{\prime} \mathrm{N}$ latitude \& $78^{\circ} 45^{\prime}$ to $81^{\circ} 05^{\prime} \mathrm{E}$ longitude) of IHR (Indian Himalayan Region) where $P$. cirrhifolium is predominantly found. A total of five different naturally occurring populations were selected and sampled randomly. Representative leaves of samples from each population were collected, placed in the coarse silica gel and brought in the laboratory for further analysis. Rhizomes of $P$. cirrhifolium were utilized to measure the phytochemicals, DNA damage preventive or antimutagenic and antioxidant activities. The experiments in the current study were conducted in the CBCM (Centre for Biodiversity Conservation and Management), Govind Ballabh Pant National Institute of Himalayan Environment (GBP-NIHE). Details of geographical coordinates and site characteristics were also recorded (Table 1).

\section{Preparation of extract}

Rhizomes of each population was separated and thoroughly washed with tap water followed by ultra pure water (Rions India Lab Water System, India). Rhizomes were dried at $40^{\circ} \mathrm{C}$ in a hot air oven and grounded into fine powder. Dried powder material $(1 \mathrm{~g})$ was added in $25 \mathrm{~mL}$ of methanol $(80 \% \mathrm{v} / \mathrm{v})$ and the suspension was incubated in water bath at $60^{\circ} \mathrm{C}$ for $1 \mathrm{~h}$. Further the suspension was kept for incubation for $24 \mathrm{~h}$ at $25^{\circ} \mathrm{C}$ and sonicated at $22^{\circ} \mathrm{C}$ for 10 minutes (Model - ANIS 09001, Toshiba, Delhi, India). After filtering the solution it was centrifuged at $22 \pm 1^{\circ} \mathrm{C}$ at $10,000 \mathrm{rpm}$ for up to 15 minutes. Thereafter, the supernatants was collected in DW and kept at $4^{\circ} \mathrm{C}$ to use within 2 days.

\section{Determination of total phenols}

Methanol extract derived from rhizome of the species was used to measure total phenolic content by Folin- Ciocalteu's colorimetric method (Singleton and Rossi 1965). Methanolic extract $(0.50 \mathrm{ml})$ was diluted with $\mathrm{dH}_{2} \mathrm{O}(4.50 \mathrm{ml})$ followed by addition of $0.50 \mathrm{ml}$ Folin-Ciocalteu's reagent. The mixture was kept at temperature for reaction up to 5 minutes. Thereafter, $5.0 \mathrm{ml}$ of sodium carbonate (7\%) was used for neutralizing the reaction and the solution was placed in dark at $25^{\circ} \mathrm{C}$ for 90 minutes. UV-vis spectrophotometer was used to record the absorbance of the solution at $765 \mathrm{~nm}$ using. The amount of total phenolics present in the extract was calculated as mg GAE (gallic acid equivalent) per g DW.

\section{Total tannins estimation}

Total tannins in the plant methanol extract were measured by applying the method developed by Nwinuka et al. (2005) with slight modification. $5 \mathrm{ml}$ of methanol extract was mixed with $0.5 \mathrm{ml}$ of Folin-Dennis reagent. The mixture was than saturated with $7 \%$ of sodium carbonate $(1.0 \mathrm{ml})$ followed by placing the solution in dark at $22 \pm 1^{\circ} \mathrm{C}$ for $20 \mathrm{~min}$. The absorbance of the solution was noted at $700 \mathrm{~nm}$ and the results were calculated as mg TAE (tannic acid equivalent) per $\mathrm{g}$ of DW.

\section{Determination of total flavonoids and flavonol}

Aluminium chloride colorimetric method was used to measure total flavonoids in the methanolic extract of the species (Chang et al. 2002). Rhizome extract $(0.50 \mathrm{ml})$ was thinned with $\mathrm{dH}_{2} \mathrm{O}(1.5 \mathrm{ml})$ and aluminium chloride $(0.50 \mathrm{ml}$ of $10 \% \mathrm{w} / \mathrm{v})$ along with addition of $1 \mathrm{M}$ potassium acetate $(0.10 \mathrm{ml})$ and $\mathrm{dH} 20(2.80 \mathrm{ml})$. The absorbance of the mixture was recorded at $415 \mathrm{~nm}$ after 30 minutes incubation at room temperature results were expressed in $\mathrm{mg}$ QE (quercetin) equivalent/ $\mathrm{g}$ of DW.

assay developed by Kumaran and Kaunakaran (2007) was applied to estimate total flavonol content in the methanol extract of the species rhizomes. Briefly, extract $(2.0 \mathrm{ml}), 2.0 \mathrm{ml} 2 \%$ ethanolic aluminium chloride $(\mathrm{w} / \mathrm{v})$ and sodium acetate solution $(3.0 \mathrm{ml})$ were added. The mixture was placed at room temperature for reaction for $2.5 \mathrm{~h}$ at $20^{\circ} \mathrm{C}$. The absorbance was recorded at $440 \mathrm{~nm}$ and the results were calculated as $\mathrm{mg}$ QE (quercetin equivalent)/g dw.

\section{Antioxidant activity}

\section{Radical scavenging activity (ABTS assay)}

Antioxidant property in the rhizome of $P$. cirrifolium was determined by ABTS method (Cai et al., 2004). ABTS cation (ABTS•+) was produced by mixing potassium persulfate $(2.45 \mu \mathrm{M})$ with $\mathrm{ABTS}$ salt $(7.0 \mu \mathrm{M})$ followed by placing solution in dark for $16 \mathrm{~h}$ at $23^{\circ} \mathrm{C}$. ABTS + solution was thinned with ethanol $(80 \%, v / v)$ to obtain an absorbance of $0.7 \pm 0.005$ at $734 \mathrm{~nm}$. ABTS•+ solution (3.90 ml) was mixed with methanolic extract $(0.10 \mathrm{ml})$ and vortexes to mix properly. The reaction mixture was placed in dark for $6 \mathrm{~min}$ at $25^{\circ} \mathrm{C}$ followed by noting absorbance at $734 \mathrm{~nm}$. Samples were diluted with methanol $(80 \%, \mathrm{v} / \mathrm{v})$ to obtain $20-80 \%$ reduction in absorbance as compared to blank that was prepared with $0.1 \mathrm{ml}$ methanol $(80 \%, \mathrm{v} / \mathrm{v})$. The results were shown as milli mole ascorbic acid equivalent (mM AAE) per $100 \mathrm{~g}$ dry weight. 


\section{Radical scavenging activity (DPPH assay)}

Slightly modified DPPH method developed by Brand-Williams et al. (1995) was used to measure DPPH activity. Briefly, DPPH (25 ml, $400 \mathrm{mM}$ ) was mixed with MES buffer in $0(25 \mathrm{ml}$ of $0.2 \mathrm{M})$. The $\mathrm{pH} 6.0$ was accustomed with $1 \mathrm{~N}$ sodium hydroxide and ethanol $(25 \mathrm{ml}$ of $20 \% \mathrm{v} / \mathrm{v})$. Sample extract $(0.9 \mathrm{ml})$ was mixed with DPPH cation solution $(2.7 \mathrm{ml})$ and placed in dark for 20 minutes at room temperature. Decrease in the absorbance was recorded at $520 \mathrm{~nm}$ and the results were calculated as mM AAE (milli mole ascorbic acid equivalent per $100 \mathrm{~g}$ of dry weight

\section{Reducing power (FRAP) assay}

Benzie and Strain (1996) assay was employed to measure the ferric reducing antioxidant power (FRAP) of the methanol extract of the

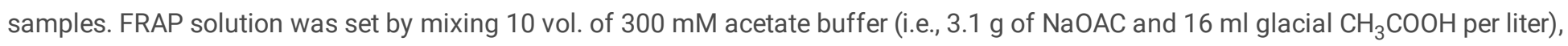
1 vol. of $10 \mathrm{mM}$ TPTZ (2,4,6-tri-2-pyridyl-1,3,5-triazin) in $40 \mathrm{mM} \mathrm{HCl}$ and 1 vol. of $20 \mathrm{mM} \mathrm{FeCl}_{3} .3 \mathrm{ml}$ of pre-warmed (at $37^{\circ} \mathrm{C}$ ) mixture was mixed to methanolic extract $(0.10 \mathrm{ml})$ and placed at $37^{\circ} \mathrm{C}$ for 8 minute. The absorbance of the solution was recorded at $593 \mathrm{~nm}$ and the results were displayed as mM AAE (milli mole of ascorbic acid equivalent)/ $100 \mathrm{~g}$ dry weight.

\section{Antimutagenic activity}

Antimutagenic (DNA damage inhibition) property of $P$. cirrhifolium extract was screened using pBR322 plasmid DNA. DNA breakage is regarded as the alteration of the super coiled (S) shape to the open-circular (OC) and/or linear (L) shape (Russo et al. 2011). Each population extracts were screened for DNA damage inhibition activity. Reaction mixture $(15 \mu \mathrm{M})$ containing $2 \mu \mathrm{M}$ of pBR322 plasmid DNA (180 ng), $2 \mu \mathrm{M}$ of $7.5 \% \mathrm{H}_{2} \mathrm{O}_{2}$, and plant extracts with positive control $(+\mathrm{C})$ and negative control $(-\mathrm{C})$ was prepared. The reaction was conducted at room temperature under UV emission for 20 minutes. Agarose gel electrophoresis was carried out using $0.8 \%$ agar in TBE buffer $(0.5 \mathrm{X})$ for $2 \mathrm{~h}$ at $45 \mathrm{~V}$. The gel was analyzed for presence of fragment and density of the fragements were estimated using Uvi pro Platinum 1.1, gel documentation system (Uvitech, Cambridge,UK). Based on band intensity, band area was calculated and finally converted into percent protection.

\section{DNA isolation}

One gram leaf tissue was sliced into sections and grounded into fine powder in liquid nitrogen. DNA extraction was performed using CTAB (cetryl trimethyl amonium bromide) scheme with slight changes (Jugran et al. 2013). DNA was electrophoresed with $1 \%$ agarose gel to verify its purity and presence. The amount of genomic DNA was determined using UV visible spectrophotometer (Hitachi, Japan). The absorbance ratio of DNA sample between 260 and $280 \mathrm{~nm}$ was measured and DNA quality was confirmed. The purified DNA sample was stored at $4^{\circ} \mathrm{C}$ for further analysis.

\section{PCR amplification}

A total of 55 RAPD and 45 ISSR primers were initially screened to amplify the DNA samples of P.cirrhifolium. Only nine RAPD and ten ISSR markers exhibited clear, reliable and reproducible fragments (Table 2). The PCR reaction was performed using a reaction mixture of $20 \mu \mathrm{l}$ in a $0.2 \mathrm{ml}$ microfuge tube with $2 \mu \mathrm{l}$ reaction buffer (10x), $2 \mu \mathrm{l}, 25 \mathrm{mM} \mathrm{MgCl}_{2}, 0.2 \mu \mathrm{M}$, each dNTPs, $0.2 \mu \mathrm{M}$ primer, $20 \mathrm{ng}$ DNA and 1 unit Taq polymerase (Genetix, India). The RAPD markers amplification programme was initiated with denaturation of $94^{\circ} \mathrm{C}$ for 4 minutes 1 cycle, final denaturation at $94^{\circ} \mathrm{C}$ for 1 minute, primer annealing $\left(37^{\circ} \mathrm{C}\right)$ for 2 minutes followed by initial extension $\left(72^{\circ} \mathrm{C}\right)$ of 2 minute and 45 cycle and final extension of PCR cycle was kept $72^{\circ} \mathrm{C}$ for 7 minutes followed by reaction hold at $4^{\circ} \mathrm{C}$.

For ISSR, denaturation was conducted for 5 minutes at $95^{\circ} \mathrm{C}$, final denaturation for 1 minute at $94^{\circ} \mathrm{C}$, primer annealing $\left(46.5-55^{\circ} \mathrm{C}\right)$ for 1 minute followed by initial extension $\left(72^{\circ} \mathrm{C}\right)$ of 2 minute and final extension of PCR cycle was kept for 7 minutes at $72^{\circ} \mathrm{C}$ followed by reaction hold at $4^{\circ} \mathrm{C}$. The amplified DNA fragements were separated using $1 \mathrm{~kb}$ DNA ladder (Genetix, India) on a agarose gel $(1.5 \%$ (w/v) for RAPD marker and $2 \%$ for ISSR marker) using TAE buffer (0.5X) and marked with Etbr (ethidium bromide) $(0.5 \mu \mathrm{g} / \mathrm{ml})$. UVI Pro platinum gel documentation system (Version 11.9, Cambridge, UK) was utilized to visualize the pattern of the gel.

\section{Statistical analysis}

Data generated for genetic diversity parameters analysis were scored in binary matrix format and used for statistical evaluation. The occurrence of band was demarcated by 1 and absence by 0 . Genetic variability attributes like frequency of the alleles, percent of polymorphic loci (Pp\%), average allele number per locus $(\mathrm{Na})$, effective number of alleles $(\mathrm{Ne})$, genetic diversity index $(\mathrm{He})$ and

Page $4 / 20$ 
Shannon Information Index (I), was estimated by using POPGENE program version 1.31 (Yeh et al. 1999). Nei genetic distances (D) between populations was analyzed using Nei (1978) and rate of gene flow using standard method (Wright, 1951). Unrooted phylogenetic trees was constructed using Neighbor-joining methods (Saitou and Nei 1987) using NEIGHBOR component of PHYLIP program version 3.68 (Felsenstein 2006). The bootstrapping at 1000 replicates was applied to measure the statistical connotation of the clusters obtained using SEQBOOT, GENEDIST, NEIGHBOR and CONSENSE programmes (Felsenstein 2006). GenAlex version 6.1 (Peakall and Smouse 2006) was used to investigate inter and intra population genetic variations by analysis of molecular variance (AMOVA).

The admixture level and cluster number among population was measured in combined RAPD and ISSR data by Bayesian assignment tests by means of STRUCTURE software version 2.3.4 (Pritchard et al. 2000). Different burning time length and number of MCMC (Markov chain Monte Carlo) replications were set to establish the appropriate set of both parameters initially. STRUCTURE was placed with a burning time length of 100,000 followed by number of MCMC reps after burning 500,000 replications by employing admixture model through previously assigned population as sampling localition and with the among populations with linked alleles frequency. Number of $K$ was established by conducting a total of ten runs $(K=1-10)$ with 3 interactions initially to decrease extra burden of simulation on computer. The maximum probable K value was predicted by $\Delta \mathrm{K}$ statistics using program Structure Harvester (Earl 2012) to estimates the utmost stage of changes between all succeeding values of $\mathrm{K}$ (Evanno et al. 2005). Concluding evaluation for each $\mathrm{K}$ value is conducted using $\mathrm{K}$ value from 1 to 5 with 20 interactions.

Data on phytochemicals and antioxidant property is analyzed as an average value \pm standard error (SE) of three separate replicates. Significant variations were estimated among average values of populations using DMRT (Duncan's multiple range test; $p<0.05$ ). Correlation coefficients ( $r$ ) and coefficients of determination (R2) were calculated through SPSS Version 17.0 (SPSS Inc., Chicago, IL, USA). R studio was used to develop a correlogram using CORRPLOT programme.

\section{Results}

\section{Total phenol, tannin, flavonol and flavonoids}

A significant variation was observed in total phenolics (1.89-3.47 mg GAE/g), tannins (1.41-2.50 mg TAE/g), flavonols (1.30-4.05 mg $\mathrm{QE} / \mathrm{g}$ ) and flavonoids (0.71-4.59 mg QE/g). Phenolic content was recorded higher (3.47mg GAE/g) in Gagar population compared to other populations (Table 3$)$. Total tannin content was found significantly $(\mathrm{p}<0.05)$ higher $(2.50 \mathrm{mg}$ TAE/g) in Gagar and lower in Satbunga population $(1.51 \mathrm{mg} \mathrm{TAE} / \mathrm{g})$.

Total flavonols was recorded significantly $(p<0.05)$ higher $(4.05 \mathrm{mg} Q \mathrm{Q} / \mathrm{g})$ in Pandavkholi population and lower in Mukteshwar $(1.30$ $\mathrm{mg} \mathrm{QE} / \mathrm{g}$ ) and Gagar (1.31 mg QE/g) populations. Similarly, total flavonoid was found maximum (4.59 mg QE/g) in Mukteshwar population and minimum ( $0.71 \mathrm{mg} \mathrm{QE} / \mathrm{g}$ ) in Gagar population.

\section{Antioxidant and DNA damage inhibition properties}

Methanol extract of the rhizomes of P.cirrhifolium evaluated for antioxidant properties by ABTS (3.26-5.12 mM AAE/100 g DW), DPPH (1.09-1.70 mM AAE/100 g DW) and FRAP (0.58-2.33 mM AAE/100 g DW) showed significant variations (Table 3). Considerably $(p<0.05)$ higher ABTS activity (5.12 mM AAE/100 g DW) found in Mukteshwar and lower in Pandavkholi (3.26 mM AAE/100 g DW). FRAP activity was recorded maximum (2.33 mM AAE/100 g DW) in Thanidar population and minimum (0.85 mM AAE/100 g DW) in Pandavkholi population. DPPH was recorded significantly $(p<0.05)$ higher $(1.70 \mathrm{mM} \mathrm{AAE} / 100 \mathrm{~g} \mathrm{DW})$ in Thanidar comparing to remaining populations except Mukteshwar (1.65 mM AAE/100 g DW) population.

Antimutagenic activity of P.cirrhifolium populations was investigated (Figure 1), which is an initial analysis of anti-mutagenic potential against oxidative stress. Gagar population showed significantly $(p<0.05)$ higher DNA recovery percentage $(84.95 \%)$ followed by Mukteshwar population (82.92\%) where as, lower recovery percentage was found in Satbunga population (67.33\%).

\section{Genetic diversity and analysis of molecular variance (AMOVA)}

Significantly higher genetic diversity was noted in all studied populations of P.cirrhifolium using RAPD and ISSR markers. Out of 33 unambiguous and reproducible bands, 30.40 (mean across population) polymorphic RAPD loci were detected. The amplified fragments ranged from 02 (OPA14) to 06 (OPJ3), with an average of 3.6 fragments per primer (Figure 2a). With an average of $92.12 \%$, the polymorphic loci percent (Pp\%) ranged from 87.88\% (Thanidar) to $96.97 \%$ (Pandavkholi). Nei gene diversity index (He) ranged 
from 0.362 (Gagar) to 0.303 (Satbunga) with an average value of 0.339 (Table 4). Shannon information index (I) ranged from 0.46 (Satbunga) to 0.53 (Gagar and Pandavkholi populations).

In case of ISSR markers out of 42 unambiguous and reproducible bands, 40 polymorphic ISSR loci were detected using 10 selected primers. The amplified fragments ranged from 03 (UBC810, UBC880, UBC888) to 07 (UBC840) (Figure 2b). With an average of 95.24\%, Pp\% ranged from $90.48 \%$ (Satbunga) to $97.62 \%$ (Mukteshwar, Gagar and Thanidar populations). He ranged from 0.253 (Satbunga) to 0.384 (Gagar) with a mean value of 0.320. I ranged from 0.391 (Satbunga) to 0.562 (Gagar) with a mean value of 0.481 (Table 4). AMOVA using RAPD marker demonstrated that the genetic variability was partitioned as $78 \%$ within populations and $22 \%$ among populations (Table 5). A value of 0.168 genetic differentiations (GST) between populations was detected. The gene flow (Nm) level measured among populations was 2.472 . Genetic diversity was partitioned as 73 percent within populations and 27 percent between populations by AMOVA using ISSR markers (Table 5). A high value of 0.221 genetic differentiations (GST) was detected between populations and gene flow was 1.759 .

\section{Cluster analysis and population structure}

RAPD markers based pairwise Nei genetic distance ) revealed minimum (0.069) genetic distance between Satbunga (2276m, grassy slopes) and Pandavkholi (2521m, rocky and boulder areas) populations and higher (0.187) genetic distance between Satbunga (2276m, grassy slopes) and Mukteshwar (2319m, grassy slopes) populations (Table 6). Nei genetic distance was observed to be lowest $(0.113)$ between Thanidar (1984m, open rocky hill slope) and Mukteshwar (2319m, grassy slope) populations and highest ( 0.250$)$ between Satbunga $(2276 \mathrm{~m}$, grassy slope) and Pandavkholi $(2521 \mathrm{~m}$, rocky and boulder areas) populations using ISSR marker (Table 6). Likewise, neighbour joining method based dendrogram separated all studied populations into 2 major groups (i.e. A and B). Group A includes Pandavkholi population and group B with 03 sub groups includes (i) Thanidar and Gagar populations; (ii) Mukteshwar and (iii) Satbunga population (Figure 3a). On the scatter plot, the principal coordinate analysis (PCA) using molecular data reflected the population's heterogeneous distribution (Figure 3b).

The first two principal components [PC 1 (41.54 percent) and PC 2 (26.84 percent)] explained 68.38 percent of the total variation when combined. The relationship among populations in two components is comparable to the clustering pattern. Similarly, dendrogram depended on ISSR markers data using neighbor joining technique divided the locations into two major groups (i.e. A and B). Group A includes Satbunga and group B includes Pandavkholi, Gagar, Mukteshwar and Thanidar. Group B was further divided into 3 subgroups (i) Pandavkholi and Gagar, (ii) Mukteshwar, (iii) Thanidar (Figure 4a). The PCA, using molecular data, reflected the diverse distribution of the population on the scatter plot (Figure 4b). The contribution of first two principal components [(PC 1(36.44\%) and PC 2 (29.72\%)] explained together $66.15 \%$ of the total variance. The relationship among populations in two components is similar to the clustering pattern. Populations structure of $P$. cirrhifolium relying on binary data obtained using both kind of markers was investigated by Pritchard et al. (2000) method revealed that the log likelihood approximations increased regularly as K increased and start to decrease when $\mathrm{K}=4$ using both markers (Figure $5 \mathrm{a}$ ). Mean log likelihood plot is prepared by placing values over 10 runs for $\mathrm{K}$ values ranging from 1 to 5 . The value of $K$ was optimum at 3 as evaluated by the $\Delta K$ statistic STRUCTURE based on utilized markers (Figure $5 b$ \&c). It was observed attractive that best possible subgroups number was reasonably lower than the total studied populations using both kind of markers, exhibited extensive amount of gene flow, either presently or historically. At probability threshold (Q) of 0.60 using ISSR markers structure analysis, the most of the genotypes were visibly isolated to a definite cluster. Of which, 16 individuals (17.78\%) were allocated to cluster-1 and cluster-2 each. Cluster-1 comprises the individuals, mainly collected from Pandavkholi population while cluster 2 possesses the individual gathered from Gagar population. Cluster 3 consist of 55 individuals (61.11\%) including the samples from Thanidar, Satbunga and Mukteshwar populations in majority; whereas only3 (3.33\%) individuals were belongs to the admixed group depending on the threshold of $60 \%$.

\section{Relationship among antioxidant, antimutagenic and genetic diversity characteristics}

Phytochemical parameters correlated with genetic diversity using RAPD and ISSR marker revealed a considerable $(p<0.05)$ positive correlation (Fig. 6a, 6b). Phenol ( $<<0.05 ; r=0.924)$ and tannin content $(p<0.05 ; r=0.897)$ attributed a noteworthy positive correlation) with nei genetic diversity $(\mathrm{He})$ using ISSR marker. Similarly, antimutagenic activity displayed a considerable positive correlation $(p<0.05 ; r=0.898)$ with He using ISSR marker. DPPH demonstrated a strong negative correlation $(p<0.01 ; r=-0.968)$ with percent of polymorphism (Pp\%) using RAPD marker. No other parameter showed relationship with genetic diversity. However, phenol revealed a 
noteworthy positive relationship $(p<0.05 ; r=-0.959)$ with tannin whereas, tannin revealed a remarkable negative correlation $(p<0.05 ; r=$ -903) with flavonol. ABTS displayed a considerable positive correlation $(p<0.05 ; r=0.885)$ with DPPH.

\section{Discussion}

Medicinal plants serve as a universal remedy for several ailments because of the potent secondary metabolites such as alkaloids, polyphenolic compounds, terpenes, carotenoids etc. These metabolites help plants to cope up with the adverse effect of oxidative stress generated through environmental variables (Suyal et al. 2019a). Phenolic compounds, tannins, flavonols and flavonoids of Himalayan medicinal herbs has been identified for their antioxidant (Giri et al. 2017), anti-inflammatory and anti-cancer activity (Singh and Patra 2018) etc. Therefore, in present study we have investigated total phenolics, tannin, flavonoid, anti-oxidant and antimutagenic activity of P.cirrhifolium which might be responsible for its medicinal properties. A significant variation was observed in total phenols (1.89-3.47 mg GAE/g), tannins (1.41-2.50 mg TAE/g), flavonols (1.30-4.05 mg QE/g) and flavonoids (0.71-4.59 mg $\mathrm{QE} / \mathrm{g})$. Antioxidant property of rhizomes derived methanolic extract of P.cirrhifolium as evaluated by ABTS (3.26-5.12 mM AAE/100 g $\mathrm{dw})$, DPPH (1.09-1.70 mM AAE/100 g dw) and FRAP (0.58-2.33 mM AAE/100 g dw) showed significant variation. These findings were in the agreement of Rawat et al. (2013) who reported tannins (2.24 mg TAE/g) and flavonoids (3.05 mg QE/g) in root extract of Habenaria edgeworthii. Similarly Giri et al. (2017) reported similar range of phenol, tannin, flavonol and antioxidant property in Astavarga species including P.cirrhifolium $(2.41 \mathrm{mg} / \mathrm{g}$ flavonoid; $3.11 \mathrm{mg} / \mathrm{g}$ tannins; $1.85 \mathrm{mg} / \mathrm{g}$ flavonol; $4.42 \mathrm{mM}$ AAE/100 g dw ABTS; $1.19 \mathrm{mM}$ AAE/100 g dw FRAP). Likewise, similar range of total tannin (2.34 mg CE/g dw) and FRAP activity (0.27-1.78 mM AAE/100 g dw) was reported in Polygonatum verticillatum (Patra and Singh, 2018; Suyal et al., 2019).

The antioxidant property of flavonoid from diverse natural resources in the prevention of cellular DNA from damage through inhibition of ROS is documented (Azqueta and Collins 2016). Inhibition of DNA damage is evaluation to detect UV tolerance as a defense arrangement of high-altitude medicinal plants (Suyal et al. 2019a). Ultra violet radiation produces hydroxyl (OH) radical by peroxidizing $\mathrm{H}_{2} \mathrm{O}_{2}$, which can damage the plasmid DNA especially the supercoiled form.

Methanolic extract of diverse rhizome part of P.cirrhifolium in different population were studied for DNA prevention activity. The rhizome extract of different population showed significant $(p<0.05)$ DNA recovery percentage which is ranged from $67.33-84.95 \%$. Therefore, extract of P.cirrhifolium and other high value medicinal plants could either check or dawdle the process of DNA damage and thus contribute to eliminate main disorders linked to DNA. Reports at the functionality of few Himalayan herbs to inhibit oxidative pressure due to DNA harm are available (Jugran et al. 2016; Giri et al. 2017; Suyal et al. 2019a). Information pertaining to genetic diversity in P.cirrhifolium is currently lacking. However, reports are available on genetic diversity studies in other species of genus Polygonatum (Kramp et al. 2009; Chung et al. 2014; Meng et al. 2014; Feng et al. 2020). Recently genetic variations of Polygonatum verticillatum populations were evaluated using ISSR markers (Suyal et al. 2021). P. cirrhifolium has been categorized as an endangered species in entire Himalayan region due to its limited population size coupled with poor regeneration (Suyal et al. 2019b), continuous harvesting, habitat degradation and grazing in the study area.

However, low variation atb genetic level is expected as a general reported trend in endangered plants with smaller population size (Manners et al. 2013). In present study, higher genetic diversity is reported in P.cirrhifolium using RAPD (He=0.339; $P p=92.12 \%)$ and ISSR ( $\mathrm{He}=0.320 ; \mathrm{Pp}=95.24 \%)$ markers. Likewise, many other threatened and endemic plant species despite of their small population size and restricted distribution, comprises high genetic diversity. For instance, Suyal et al. (2021) reported high $(\mathrm{He}=0.32 ; \mathrm{Pp} \%=85.49 \%)$ genetic variations in P. verticillatum using ISSR marker. Similarly, Naik et al. (2010) reported higher level $(\mathrm{He}=0.34 ; \mathrm{Pp} \%=92.37)$ of genetic variations in endangered Podophyllum hexandrum using RAPD marker; Tabin et al. (2016) in Rheum webbianum (He=0.34; $\mathrm{Pp} \%=87 \%$ ) using ISSR markers; Chaudhery et al. (2012) in Hedychium spicatum (RAPD- $\mathrm{He}=0.44 ; \mathrm{Pp}=89.58 \%$ ). The higher genetic diversity in P.cirrhifolium might be due to its population distribution in different geographical conditions. In different geographical conditions the plant species may differ in their content due to diverse environmental variables (altitude, temperature, rainfall, humidity, etc.) and breeding system of the species (Zhang et al. 2020). Understanding the genetic variations inside and among populations is critical for basis of powerful and efficient conservation practices for rare species.

Most of the phenotypic variations, in P.cirrhifolium allotted inside population [RAPD- 78\%; ISSR-73\%]. These results of within population variations are in line with reported variation for some endangered orchids and other threatened herbs e.g., Dendrobium officinale [RAPD- 78.88\%; ISSR-78.84\%]; Fritillaria tubiformis subsp. moggridgei [RAPD-82.91\%], Habenaria edgeworthii [ISSR- 74\%] respectively [Ding et al. 2009; Mucciarelli et al. 2014; Giri et al. 2016]. The higher intra population variability of $P$. cirrhifolium can be elucidated based on its life history traits, particularly due to its breeding system. Breeding system of a plant species was found to

Page $7 / 20$ 
influence the distribution of cistrontic diversity in plant populations. Additionally, factors like habitat disintegration, gene flow, and tiny population size additionally reported to contribute to the present difference (Nybom 2004).

The constant of genetic discrimination (GST) and gene flow (Nm) are two important parameters by which the genetic structure of population are often measured. Low genetic discrimination was recorded using RAPD and ISSR markers in P.cirrhifolium [RAPD: GST= 0.168; ISSR: GST $=0.221$ ] although it was comparable to the average coefficients i.e. GST $=0.22$ reported for out-crossing species (Nybom 2004) and GST $=0.231$ for monocots (Hamrick and Godt 1990). Similar low genetic differentiation as reported elsewhere (Naik et al. 2010; Tiwari et al. 2015).

Factors like geographical isolation, small population size of target species, habitat fragmentation and genetic drift could be responsible for low genetic differentiation (Tiwari et al. 2015; Suyal et al. 2019b). A relatively high correlation between chemotypic and genetic markers were identified. Giri et al. 2016, observed similar results in $\mathrm{H}$. edgeworthi, where ISSR marker revealed a noteworthy correlation with total phenolics [t=3.196; $p<0.09$ ]; Jugran et al. (2016) in Valeriana jatamansi [ABTS with (DPPH, $r=0.482 ; p<0.05 ; F R A P$, $r=0.637 ; p<0.01)$ ]; and Suyal et al. (2019a) in P. verticillatum [ABTS (DPPH, $r=0.544 ; p<0.05)$ ].

\section{Conclusion}

This study is the first account on the phytochemical properties and genetic diversity of P.cirrhifolium. Populations of $P$. cirrhifolium is restricted to specialized small patches and are threatened in wild due to destructive harvesting. Considering habitat specificity, low plant density, and increasing extraction trends, the species need immediate conservation intervention. Genetic diversity assessment, therefore, is important to define conservation interventions for survival of genetic resources particularly of threatened plants with low population density. The Gagar population, with highest genetic variation, phenolic, tannin and antimutagenic property should be considered by priority as an important reservoir of potentially useful genes as the species shows enormous potential to adapt to altering environmental conditions.

\section{Declarations}

\section{Acknowledgment}

The authors are thankful to Director, GBPNIHE, Kosi-Katarmal, Almora for facilities and encouragement. Help obtained from the members of BCM \& BTA Theme is highly acknowledged.

\section{Statements and Declarations}

The authors declare that they have no known competing financial interests or personal relationships that could have appeared to influence the work reported in this paper.

\section{Funding}

This work was supported under Botanical Garden Scheme of Ministry of Environment, Forest and Climate change (MoEF\&CC), New Delhi (F.N. BSI-290/6/2013- Tech; Dated 29/09/2013) and Project No. 4 (In house project) funded to CBCM group by GB Pant National Institute (MoEF\&CC).

\section{Conflicts of interest}

All authors declare no conflicts of interest in publishing this MS.

\section{Availability of data and material}

All data linked with this MS is available within this Manuscript.

\section{Code availability}

\section{NA}

\section{Author contribution}


RS, AKJ, and IDB conceptualized the study. RS and AKJ standardized methodology and conducted the experiments. AKJ performed data analysis. IBD contributed in management of resources and funds. RS and AKJ contributed in Writing - Original Draft of the MS. All authors contributed in Writing - Review \& Editing of the manuscript.

\section{Ethics approval}

This MS is the authors' own original work, which has not been previously published elsewhere. The paper is not currently being considered for publication elsewhere. The paper reflects the authors' own research and analysis in a truthful and complete manner.

\section{Consent to participate}

NA

\section{Consent for publication}

All the authors are informed and agreed to submit this manuscript to the GRCE Journal for publication.

\section{References}

1. Azqueta A, Collins A (2016) Polyphenols and DNA damage: A mixed blessing. Nutrients $8: 785$

2. Balkrishna A, Srivastava A, Mishra RK, Patel SP, Vashistha RK, Singh A, Jadon V, Saxena P (2012) Astavarga plants-threatened medicinal herbs of the North-West Himalaya. Int J Medicinal Aromat Plants 2:661-676

3. Benzie IF, Strain JJ (1996) The ferric reducing ability of plasma (FRAP) as a measure of antioxidant power: the FRAP assay. Annal Biochem 239:70-76. https://doi.org/10.1006/abio.1996.0292

4. Brand-Williams W, Cuvelier ME, Berset CLWT (1995) Use of a free radical method to evaluate antioxidant activity. LWT-Food Sci Technol 28:25-30. https://doi.org/10.1016/S0023-6438(95)80008-5

5. Cai Y, Luo Q, Sun M, Corke H (2004) Antioxidant activity and phenolic compounds of 112 traditional Chinese medicinal plants associated with anticancer. Life Sci 74:2157-2184. https://doi.org/10.1016/j.lfs.2003.09.047

6. Chang CC, Yang MH, Wen HM, Chern JC (2002) Estimation of total flavonoid content in propolis by two complementary colorimetric methods. J Food Drug Anal 10:178-182. https://doi.org/10.38212/2224-6614.2748

7. Chaudhary AA, Dhar U, Ahmad A, Bhatt ID, Jugran A, Kaur G (2012) Analysis of genetic diversity in Hedychium spicatum Buch. Ham. ex. D. Don in West Himalaya, India. J Med Plant Res 6:3984-3991. https://doi.org/10.5897/JMPR12.014

8. Chung MY, López-Pujol J, Chung JM, Kim KJ, Chung MG (2014) Contrasting levels of clonal and within-population genetic diversity between the 2 ecologically different herbs Polygonatum stenophyllum and Polygonatum inflatum (Liliaceae). J Hered 105:690-701. https://doi.org/10.1093/jhered/esu048

9. Ding G, Li X, Ding X, Qian L (2009) Genetic diversity across natural populations of Dendrobium officinale, the endangered medicinal herb endemic to China, revealed by ISSR and RAPD markers. Russ J Genet 45:327-334.

https://doi.org/10.1134/S1022795409030119

10. Earl DA (2012) STRUCTURE HARVESTER: a website and program for visualizing STRUCTURE output and implementing the Evanno method. Conserv Genet Resour 4:359-361. https://doi.org/10.1007/s12686-011-9548-7

11. Evanno G, Regnaut S, Goudet J (2005) Detecting the number of clusters of individual using the software STRUCTURE: a simulation study. Mol Ecol 14:2611-2620. https://doi.org/10.1111/j.1365-294X.2005.02553.x

12. Fang HL, Nie W, Zhu PL, Liang CY, Deng SY (2018) Genetic diversity in Callicarpa kwangtungensis Chun. based on morphological, biochemical and ISSR markers. J Appl Res Med Aromat Plants 10:41-48

13. Felsenstein J (2006) PHYLIP (phylogenetic inference package) documentation files, version 3.66. Department of Genome Sciences, University of Washington, Seattle, USA. https://doi.org/10.1016/j.jarmap.2018.06.001

14. Feng T, Jia Q, Meng X, Chen X, Wang F, Chai W, Liang Z (2020) Evaluation of genetic diversity and construction of DNA fingerprinting in Polygonatum Mill. based on EST-SSR and SRAP molecular markers. https://doi.org/10.1007/s13205-020-02316-

Page 9/20 


\section{z. 3 Biotech}

15. Giri L, Belwal T, Bahukhandi A, Suyal R, Bhatt ID, Rawal RS, Nandi SK (2017) Oxidative DNA damage protective activity and antioxidant potential of Ashtvarga species growing in the Indian Himalayan Region. Ind Crops Prod 102:173-179. https://doi.org/10.1016/j.indcrop.2017.03.023

16. Jugran AK, Bahukhandi A, Dhyani P, Bhatt ID, Rawal RS, Nandi SK, Dhar U (2016) Population genetic structure and marker trait associations using morphological, phytochemical and molecular parameters in Habenaria edgeworthii-a threatened medicinal orchid of West Himalaya, India. Appl Biochem Biotechnol 181:267-282. https://doi.org/10.1007/s12010-016-2211-8

17. Hamric JL, Godt MW (1990) Allozyme diversity in plant species. Plant Population Genetics, Breeding, and Genetic Resources. Sinauer Associates Inc., Sunderland, Massachusetts, USA, pp 43-63

18. Hirai N, Miura T, Moriyasu M, Ichimaru M, Nishiyama Y, Ogura K, Kato A (1997) Cardiotonic activity of the rhizome of Polygonatum sibiricum in rats. Biol Pharm Bull 20:1271-1273. https://doi.org/10.1248/bpb.20.1271

19. Jugran AK, Bahukhandi A, Dhyani P, Bhatt ID, Rawal RS, Nandi SK (2016) Impact of altitudes and habitats on Valerenic acid, total phenolics, flavonoids, tannins, and antioxidant activity of Valeriana jatamansi. Appl Biochem Biotechnol 179:911-926. https://doi.org/10.1007/s12010-016-2039-2

20. Jugran AK, Bhatt ID, Rawal RS, Nandi SK, Pande V (2013) Patterns of morphological and genetic diversity of Valeriana jatamansi Jones in different habitats and altitudinal range of West Himalaya, India. Flora 208:13-21. https://doi.org/10.1016/j.flora.2012.12.003

21. Khan H, Saeed M, Gilani AH, Muhammad N, ur Rehman N, Mehmood MH, Ashraf N (2016) Antispasmodic and antidiarrheal activities of rhizomes of Polygonatum verticillatum maneuvered predominately through activation of $\mathrm{K}+$ channels: components identification through TLC. Toxicol Ind Health 32:677-685. https://doi.org/10.1177/0748233713506956

22. Khan H, Saeed M, Mehmood MH, Rehman NU, Muhammad N, Haq IU, Ashraf N, El-Tahir KEH, Gilani AH (2013) Studies on tracheorelaxant and anti-inflammatory activities of rhizomes of Polygonatum verticillatum. BMC Complement Altern Med. https://doi.org/10.1186/1472-6882-13-197

23. Kramp K, Huck S, Niketic M, Tomovic G, Schmitt T (2009) Multiple glacial refugia and complex postglacial range shifts of the obligatory woodland plant Polygonatum verticillatum (Convallariaceae). Plant Biol 11:392-404. https://doi.org/10.1111/j.14388677.2008.00130.x

24. Liu XX, Wan ZJ, Shi L, Lu XX (2011) Preparation and antiherpetic activities of chemical modified polysaccharides from Polygonatum cyrtonema Hua. Carbohydr polym 83:737-742. https://doi.org/10.1016/j.carbpol.2010.08.044

25. Manners V, Kumaria S, Tandon P (2013) SPAR methods revealed high genetic diversity within populations and high gene flow of Vanda coerulea Griff ex Lindl (Blue Vanda), an endangered orchid species. Gene 519:91-97. https://doi.org/10.1016/j.gene.2013.01.037

26. Meng Y, Nie ZL, Deng T, Wen J, Yang YP (2014) Phylogenetics and evolution of phyllotaxy in the Solomon's seal genus Polygonatum (Asparagaceae: Polygonateae). Bot J Linn Soc 176:435-451. https://doi.org/10.1111/boj.12218

27. Mucciarelli M, Ferrazzini D, Belletti P (2014) Genetic variability and population divergence in the rare Fritillaria tubiformis subsp. moggridgei Rix (Liliaceae) as revealed by RAPD analysis. PLoS ONE. https://doi.org/10.1371/journal.pone.0101967

28. Naik PK, Alam MA, Singh H, Goyal V, Parida S, Kalia S, Mohapatra T (2010) Assessment of genetic diversity through RAPD, ISSR and AFLP markers in Podophyllum hexandrum: a medicinal herb from the Northwestern Himalayan region. Physiol Mol Biol Plants 16:135-148. https://doi.org/10.1007/s12298-010-0015-9

29. Nei M (1978) Estimation of average heterozygosity and genetic distance from a small number of individuals. Genetics 89:583590. https://doi.org/10.1093/genetics/89.3.583

30. Nybom H (2004) Comparison of different nuclear DNA markers for estimating intraspecific genetic diversity in plants. Mol Ecol 13:1143-1155. https://doi.org/10.1111/j.1365-294X.2004.02141.x

31. Peakall ROD, Smouse PE (2006) GENALEX 6: genetic analysis in Excel. Population genetic software for teaching and research. Mol Ecol Notes 6:288-295. https://doi.org/10.1111/j.1471-8286.2005.01155.x

32. Pritchard JK, Stephens M, Donnelly P (2000) Inference of population structure using multilocus genotype data. Genetics 155:945959. https://doi.org/10.1093/genetics/155.2.945

33. Rawat S, Andola H, Giri L, Dhyani P, Jugran A, Bhatt ID, Rawal RS (2013) Assessment of nutritional and antioxidant potential of selected vitality strengthening Himalayan medicinal plants. Int J Food Prop 17:703-712.

Page 10/20 
https://doi.org/10.1080/10942912.2012.654563

34. Ray A, Jena S, Haldar T, Sahoo A, Kar B, Patnaik J, Ghosh B, Panda PC, Mahapatra N, Nayak S (2019) Population genetic structure and diversity analysis in Hedychium coronarium populations using morphological, phytochemical and molecular markers. Ind Crops Prod 132:118-133. https://doi.org/10.1016/j.indcrop.2019.02.015

35. Russo A, Cardile V, Caggia S, Gunther G, Troncoso N, Garbarino J (2011) Boldo prevents UV light and nitric oxide mediated plasmid DNA damage and reduces the expression of Hsp70 protein in melanoma cancer cells. J Pharm Pharmacol 63:12191229. https://doi.org/10.1111/j.2042-7158.2011.01320.x

36. Saitou N, Nei M (1987) The neighbor-joining method: a new method for reconstructing phylogenetic trees. Mol Biol Evol 4:406425. https://doi.org/10.1093/oxfordjournals.molbev.a040454

37. Singh SK, Patra A (2019) Evaluation of adaptogenic potential of Polygonatum cirrhifolium (Wall.) Royle: in vitro, in vivo and in silico studies. S Afr J Bot 121:159-177. https://doi.org/10.1016/j.sajb.2018.10.022

38. Singleton VL, Rossi JA (1965) Colorimetry of total phenolics with phosphomolybdic-phosphotungstic acid reagents. Am J Enol Vitic 16:144-158

39. Suyal R, Bhatt D, Rawal RS, Tewari LM (2019b) Status of Two Threatened Astavarga Herbs, Polygonatum cirrhifolium and Malaxis muscifera, in West Himalaya: Conservation Implications. Proc Natl Acad Sci India B Biol Sci. https://doi.org/10.1007/s40011-019-01144-3

40. Suyal R, Jugran AK, Rawal RS, Bhatt ID (2021) Morphological, phytochemical and genetic diversity of threatened Polygonatum verticillatum (L.) All. populations of different altitudes and habitat types in Himalayan region. Physiol Mol Biol Plants. https://doi.org/10.1007/s12298-021-01044-9

41. Suyal R, Rawat S, Rawal RS, Bhatt ID (2019a) Variability in morphology, phytochemicals, and antioxidants in Polygonatum verticillatum (L.) All. populations under different altitudes and habitat conditions in Western Himalaya, India. https://doi.org/10.1007/s10661-019-7687-6. Environ Monit Assess

42. Tabin S, Kamili AN, Ganie SA, Zargar O, Sharma V, Gupta RC (2016) Genetic diversity and population structure of Rheum species in Kashmir Himalaya based on ISSR markers. Flora 223:121-128. https://doi.org/10.1016/j.flora.2016.05.001

43. Tiwari V, Mahar KS, Singh N, Meena B, Nair KN, Datt B, Upreti DK, Tamta S, Rana TS (2015) Genetic variability and population structure of Bergenia ciliata (Saxifragaceae) in the Western Himalaya inferred from DAMD and ISSR markers. Biochem Syst Ecol 60:165-170. https://doi.org/10.1016/j.bse.2015.04.018

44. Wang D, Song X, Li J (2006) Extraction and isolation technology of polysaccharides from Polygonatum cirrhifolium Root. J Northwest For Univ 21:158

45. Wang W, Dabu X, He J, Yang H, Yang S, Chen J, Fan W, Zhang G, Cai J, Ai H, Hai M (2019) Polygonatone H, a new homoisoflavanone with cytotoxicity from Polygonatum cyrtonema Hua. Nat Prod Res 33:1727-1733.

https://doi.org/10.1080/14786419.2018.1434645

46. Wright S (1951) The genetical structure of populations. Ann Eugen 15:323-354. https://doi.org/10.1111/j.14691809.1949.tb02451.x

47. Yeh FC, Boyle T, Rongcai Y, Ye Z, Xian JM (1999) POPGENE, version 1.31. A Microsoft Window Based Freeware for Population Genetic Analysis. University of Alberta, Edmonton, Canada. https://www.ualberta.ca/fyeh/popgene.download.html

48. Xu Y, Lin W, Ye S, Wang H, Wang T, Su Y, Wu L, Wang Y, Xu Q, Cai J (2017) Protective effects of an ancient chinese kidney-tonifying formula against $\mathrm{H} 2 \mathrm{O} 2$-induced oxidative damage to MES23.5 cells. https://doi.org/10.1155/2017/2879495. Parkinson's disease

49. Zhang X, Kong W, Wang X, Zhang J, Liu L, Wang W, Zhang H, Deng Q (2020) Genetic diversity analysis of 34 fig varieties (Ficus carica L.) based on ISSR molecular marker. Genet Resour and Crop Evol 67:913-921. https://doi.org/10.1007/s10722-020-008895

50. Zhao P, Zhao C, Li X, Gao Q, Huang L, Xiao P, Gao W (2018) The genus Polygonatum: A review of ethnopharmacology, phytochemistry and pharmacology. J Ethnopharmacol 214:274-291. https://doi.org/10.1016/j.jep.2017.12.006

\section{Tables}

\section{Table 1}

Details of P.cirrhifolium samples collected from different geographical location and site characteristics

Page $11 / 20$ 


\begin{tabular}{|c|c|c|c|c|c|}
\hline \multirow[t]{3}{*}{ Location } & \multicolumn{3}{|c|}{ Geographical parameters } & \multirow[t]{3}{*}{ Habitat } & \multirow[t]{3}{*}{ Collection number } \\
\hline & Altitude & Latitude & Longitude & & \\
\hline & (m asl) & $\left({ }^{\circ} \mathrm{N}\right)$ & $\left({ }^{\circ} \mathrm{E}\right)$ & & \\
\hline Thanidar & 1984 & $29^{\circ} 58^{\prime} 5.88^{\prime \prime}$ & $80^{\circ} 36^{\prime} 34.56^{\prime \prime}$ & Rocky hill slope & GBP5354 \\
\hline Gagar & 2163 & $29^{\circ} 26^{\prime} 2.04^{\prime \prime}$ & 79³6'5.76" & Moist grassy & GBP 5357 \\
\hline Satbunga & 2276 & $29^{\circ} 26^{\prime} 2.40^{\prime \prime}$ & $79^{\circ} 36^{\prime} 3.60^{\prime \prime}$ & Moist grassy & GBP 5358 \\
\hline Mukteshwar & 2319 & $29^{\circ} 28^{\prime} 30.00^{\prime \prime}$ & $79^{\circ} 38^{\prime} 43.80^{\prime \prime}$ & Open grassy, shady & GBP 5356 \\
\hline Pandavkholi & 2521 & $29^{\circ} 50^{\prime} 2.04^{\prime \prime}$ & $79^{\circ} 28^{\prime} 14.88^{\prime \prime}$ & Rocky/boulder & GBP 5365 \\
\hline
\end{tabular}

\section{Table 2}

Details of RAPD and ISSR primers used in the analysis of genetic diversity of 90 genotypes of P.cirrhifolium

\begin{tabular}{|c|c|c|c|c|}
\hline Marker & Primer name & Sequence (5囚-3') & Annealing temperature & No. of fragment amplified \\
\hline \multirow[t]{9}{*}{ RAPD } & OPJ3 & TCTCCGCTTG & $37^{\circ} \mathrm{C}$ & 6 \\
\hline & OPA3 & AGT CAG CCA C & $37^{\circ} \mathrm{C}$ & 3 \\
\hline & OPA8 & GTG ACG TAG G & $37^{\circ} \mathrm{C}$ & 4 \\
\hline & OPA9 & GGG TAA CGC C & $37^{\circ} \mathrm{C}$ & 3 \\
\hline & OPA12 & TCG GCG ATA G & $37^{\circ} \mathrm{C}$ & 4 \\
\hline & OPA13 & CAG CAC CCA C & $37^{\circ} \mathrm{C}$ & 4 \\
\hline & OPA19 & CAA ACG TCG G & $37^{\circ} \mathrm{C}$ & 3 \\
\hline & OPA20 & GTTGCGATCC & $37^{\circ} \mathrm{C}$ & 4 \\
\hline & OPA14 & TCTGTGCTGG & $37^{\circ} \mathrm{C}$ & 2 \\
\hline \multirow[t]{10}{*}{ ISSR } & UBC840 & GAGAGAGAGAGAGAGAYT & $55^{\circ} \mathrm{C}$ & 7 \\
\hline & HB12 & CACCACCACGC & $46.5^{\circ} \mathrm{C}$ & 5 \\
\hline & HB13 & GAGGAGGAGGC & $53^{\circ} \mathrm{C}$ & 5 \\
\hline & UBC860 & TGTGTGTGTGTGTGTGRA & $55^{\circ} \mathrm{C}$ & 4 \\
\hline & UBC880 & GGAGAGGAGAGGAGA & $52{ }^{\circ} \mathrm{C}$ & 3 \\
\hline & UBC859 & TGTGTGTGTGTGTGTGRC & $55^{\circ} \mathrm{C}$ & 4 \\
\hline & 17898B & CACACACACACAGT & $53^{\circ} \mathrm{C}$ & 4 \\
\hline & UBC810 & GAGAGAGAGAGAGAGAT & $55^{\circ} \mathrm{C}$ & 3 \\
\hline & HB9 & GTGTGTGTGTGTGG & $46.5^{\circ} \mathrm{C}$ & 4 \\
\hline & UBC888 & BDBCACACACACACACA & $52{ }^{\circ} \mathrm{C}$ & 3 \\
\hline
\end{tabular}

$B=(C, G, T)$ (i.e., not $A) ; D=(A, G, T)$ (i.e., not $C) ; R=(A, G) ; Y=(C, T)$

\section{Table 3}

Phytochemical composition, antioxidant and antimutagenic activity in selected population of P.cirrhifolium 


\begin{tabular}{|lllllllll|}
\hline Population & Phenol & Tannin & Flavonol & Flavonoid & ABTS & FRAP & DPPH & AMA \\
\hline & mg GAE/g & mg TAE/g & mg QE/g & mg QE/g & mM AAE/ $100 \mathrm{~g} \mathrm{dw}$ & & \\
\hline Thanidar & $1.89 \pm 0.05^{\mathrm{c}}$ & $1.54 \pm 0.02^{\mathrm{c}}$ & $3.41 \pm 0.02^{\mathrm{b}}$ & $1.83 \pm 0.01^{\mathrm{b}}$ & $4.59 \pm 0.08^{\mathrm{b}}$ & $2.33 \pm 0.01^{\mathrm{a}}$ & $1.70 \pm 0.02^{\mathrm{a}}$ & $72.32 \pm 1.55^{\mathrm{ab}}$ \\
\hline Gagar & $3.47 \pm 0.01^{\mathrm{a}}$ & $2.50 \pm 0.01^{\mathrm{a}}$ & $1.31 \pm 0.07^{\mathrm{d}}$ & $0.71 \pm 0.04^{\mathrm{d}}$ & $4.06 \pm 0.03^{\mathrm{c}}$ & $1.05 \pm 0.01^{\mathrm{c}}$ & $1.58 \pm 0.01^{\mathrm{b}}$ & $84.95 \pm 7.27^{\mathrm{a}}$ \\
\hline Satbunga & $1.80 \pm 0.04^{\mathrm{c}}$ & $1.51 \pm 0.01^{\mathrm{c}}$ & $2.43 \pm 0.01^{\mathrm{c}}$ & $1.83 \pm 0.01^{\mathrm{b}}$ & $3.29 \pm 0.07^{\mathrm{d}}$ & $0.58 \pm 0.02^{\mathrm{e}}$ & $1.30 \pm 0.01^{\mathrm{c}}$ & $67.33 \pm 1.58^{\mathrm{b}}$ \\
\hline Mukteshwar & $2.80 \pm 0.06^{\mathrm{b}}$ & $2.34 \pm 0.05^{\mathrm{b}}$ & $1.30 \pm 0.01^{\mathrm{d}}$ & $4.59 \pm 0.01^{\mathrm{a}}$ & $5.12 \pm 0.31^{\mathrm{a}}$ & $1.18 \pm 0.01^{\mathrm{b}}$ & $1.65 \pm 0.03^{\mathrm{a}}$ & $82.92 \pm 2.66^{\mathrm{a}}$ \\
\hline Pandavkholi & $2.00 \pm 0.13^{\mathrm{c}}$ & $1.41 \pm 0.01^{\mathrm{d}}$ & $4.05 \pm 0.02^{\mathrm{a}}$ & $0.79 \pm 0.01^{\mathrm{c}}$ & $3.26 \pm 0.13^{\mathrm{d}}$ & $0.85 \pm 0.01^{\mathrm{d}}$ & $1.09 \pm 0.01^{\mathrm{d}}$ & $79.03 \pm 3.50^{\mathrm{ab}}$ \\
\hline
\end{tabular}

ABTS-2,2'-azino-bis(3-ethylbenzothiazoline-6-sulfonic acid; FRAP- ferric reducing antioxidant power assay; DPPH-2,2-diphenyl-1-picrylhydrazyl-hydrate; AMA- anti mutagenic activity; *; **; **; \#

\section{Table 4}

Genetic diversity analysis of P.cirrhifolium in studied populations using RAPD and ISSR markers

\begin{tabular}{|llllllll|}
\hline Marker & Populations & $\mathrm{Np}$ & $\mathrm{Pp}(\%)$ & $\mathrm{Na}$ & $\mathrm{Ne}$ & $\mathrm{l}$ & $\mathrm{He}$ \\
\hline RAPD & Thanidar & 29 & 87.88 & $1.82 \pm 0.09$ & $1.59 \pm 0.05$ & $0.51 \pm 0.04$ & $0.34 \pm 0.03$ \\
& Gagar & 30 & 90.91 & $1.85 \pm 0.09$ & $1.64 \pm 0.05$ & $0.53 \pm 0.04$ & $0.36 \pm 0.03$ \\
& Satbunga & 31 & 93.94 & $1.94 \pm 0.04$ & $1.50 \pm 0.05$ & $0.46 \pm 0.04$ & $0.30 \pm 0.03$ \\
& Mukteshwar & 30 & 90.91 & $1.91 \pm 0.07$ & $1.56 \pm 0.06$ & $0.49 \pm 0.04$ & $0.33 \pm 0.03$ \\
\hline & Pandavkholi & 32 & 96.97 & $1.97 \pm 0.03$ & $1.62 \pm 0.05$ & $0.53 \pm 0.03$ & $0.36 \pm 0.02$ \\
\hline \multirow{2}{*}{ ISSR } & Mean & 30.4 & 92.12 & $1.89 \pm 0.03$ & $1.58 \pm 0.02$ & $0.50 \pm 0.02$ & $0.34 \pm 0.01$ \\
& Thanidar & 41 & 97.62 & $1.98 \pm 0.02$ & $1.52 \pm 0.05$ & $0.48 \pm 0.03$ & $0.31 \pm 0.02$ \\
\hline & Gagar & 41 & 97.62 & $1.98 \pm 0.05$ & $1.67 \pm 0.04$ & $0.56 \pm 0.02$ & $0.38 \pm 0.02$ \\
\hline & Satbunga & 38 & 90.48 & $1.91 \pm 0.06$ & $1.41 \pm 0.05$ & $0.39 \pm 0.04$ & $0.25 \pm 0.03$ \\
& Mukteshwar & 41 & 97.62 & $1.98 \pm 0.02$ & $1.61 \pm 0.05$ & $0.53 \pm 0.03$ & $0.36 \pm 0.02$ \\
\hline & Pandavkholi & 39 & 92.86 & $1.93 \pm 0.04$ & $1.49 \pm 0.05$ & $0.45 \pm 0.03$ & $0.30 \pm 0.03$ \\
\hline & Mean & 40 & 95.24 & $1.95 \pm 0.02$ & $1.54 \pm 0.02$ & $0.48 \pm 0.01$ & $0.32 \pm 0.01$ \\
\hline
\end{tabular}

Np - Number of polymorphic loci; Pp\% - Percentage of polymorphic loci; $\mathrm{Na}$ - Observed number of alleles; $\mathrm{Ne}$ - Effective number of alleles; He - Nei' s (1973) gene diversity; I-Shannon's Information index

\section{Table 5}

Analysis of molecular variance (AMOVA) based on RAPD and ISSR markers 


\begin{tabular}{|c|c|c|c|c|c|c|}
\hline Marker & $\begin{array}{l}\text { Source of } \\
\text { variation }\end{array}$ & $\begin{array}{l}\text { Degree of freedom } \\
\text { (df) }\end{array}$ & $\begin{array}{l}\text { Sum of square } \\
\text { (SS) }\end{array}$ & MS & $\begin{array}{l}\text { Variance } \\
\text { component }\end{array}$ & $\begin{array}{l}\text { Percentage of total } \\
\text { variance }\end{array}$ \\
\hline \multirow[t]{3}{*}{ RAPD } & $\begin{array}{l}\text { Among } \\
\text { Population }\end{array}$ & 4 & 148.510 & 37.128 & 1.730 & $22 * \star$ \\
\hline & $\begin{array}{l}\text { Within } \\
\text { Population }\end{array}$ & 85 & 528.200 & 6.214 & 6.214 & 78 ** \\
\hline & Total & 89 & 676.710 & & 7.944 & 100 \\
\hline \multirow[t]{3}{*}{ ISSR } & $\begin{array}{l}\text { Among } \\
\text { Population }\end{array}$ & 4 & 226.733 & 56.683 & 2.731 & $27^{\star \star}$ \\
\hline & $\begin{array}{l}\text { Within } \\
\text { Population }\end{array}$ & 85 & 639.333 & 7.522 & 7.522 & $73^{* *}$ \\
\hline & Total & 89 & 866.067 & & 10.253 & 100 \\
\hline
\end{tabular}

\section{Table 6}

Nei's Unbiased Measures of Genetic Identity and Genetic distance using RAPD marker

\begin{tabular}{|lllllll|}
\hline Marker & Population & Mukteshwar & Pandavkholi & Gagar & Thanidar & Satbunga \\
\hline RAPD & Mukteshwar & 0 & & & & \\
& Pandavkholi & 0.146 & 0 & & & \\
& Gagar & 0.126 & 0.118 & 0 & & \\
\hline & Thanidar & 0.121 & 0.120 & 0.078 & 0 & \\
\hline & Satbunga & 0.187 & 0.069 & 0.132 & 0.136 & 0 \\
\hline ISSR & Mukteshwar & 0 & & & & \\
\hline & Pandavkholi & 0.165 & 0 & & & \\
\hline & Gagar & 0.131 & 0.129 & 0 & & \\
\hline & Thanidar & 0.113 & 0.225 & 0.15 & 0 & \\
\hline
\end{tabular}

\section{Figures}




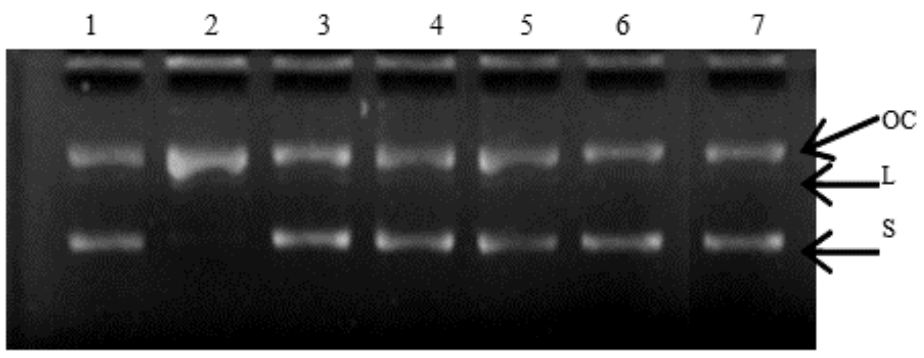

Fig. 1

\section{Figure 1}

Antimutagenic activity of P.cirrhifolium extract. Lane 1- only pBR322; lane 2- pBR322, $\mathrm{H}_{2} \mathrm{O}_{2}$ and UV exposure; lane 3,4,5,6 and 7damage pBR322 treated with extract 

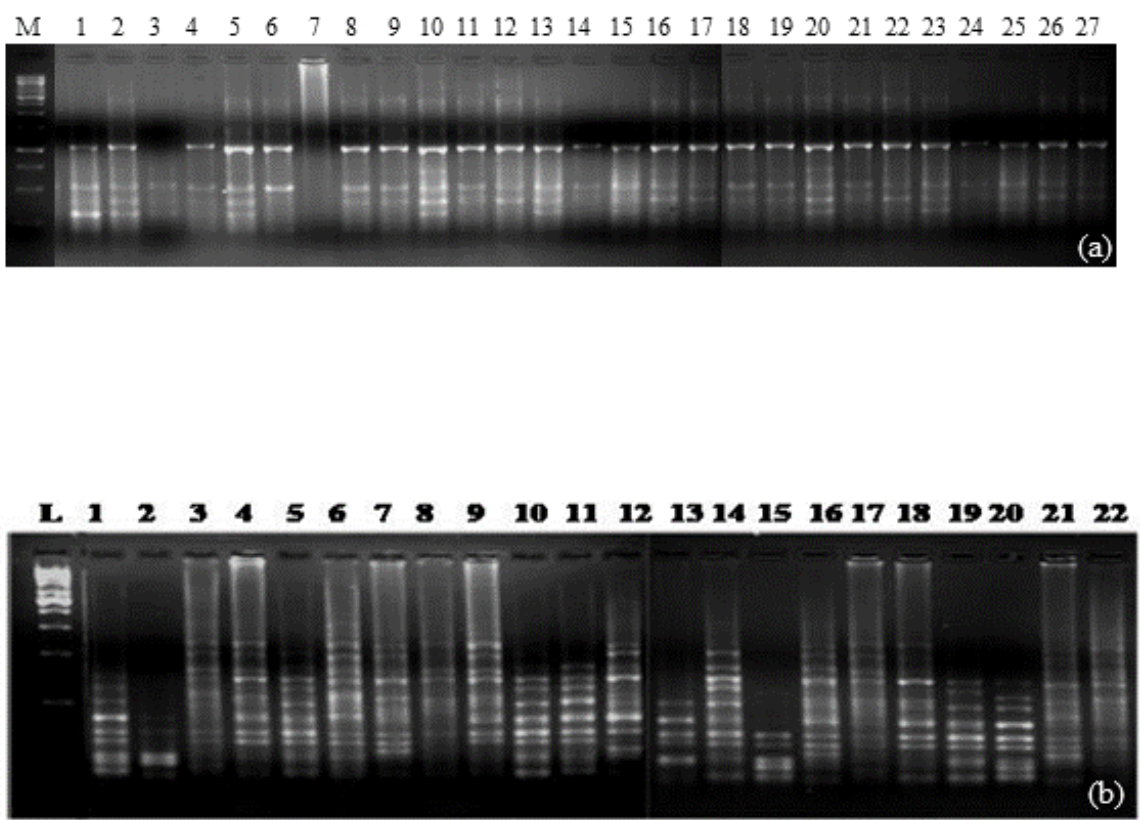

Fig. 2

Figure 2

PCR amplification pattern of P.cirrhifolium (a) obtained by OPA8 RAPD markers; (b) UBC 840 ISSR marker 


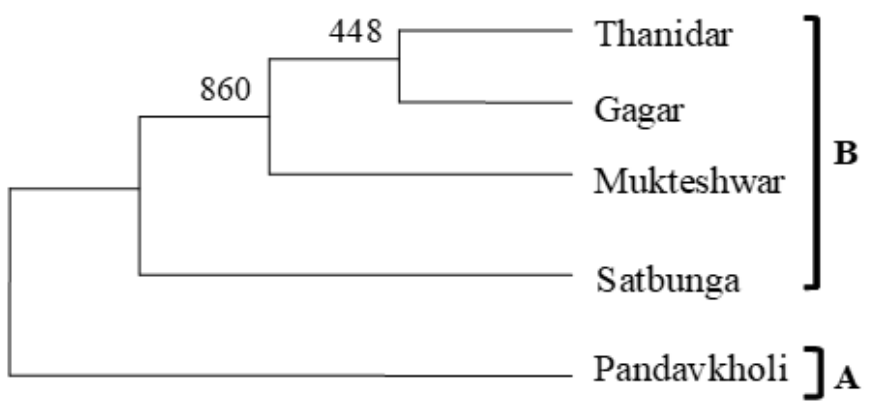

(a)

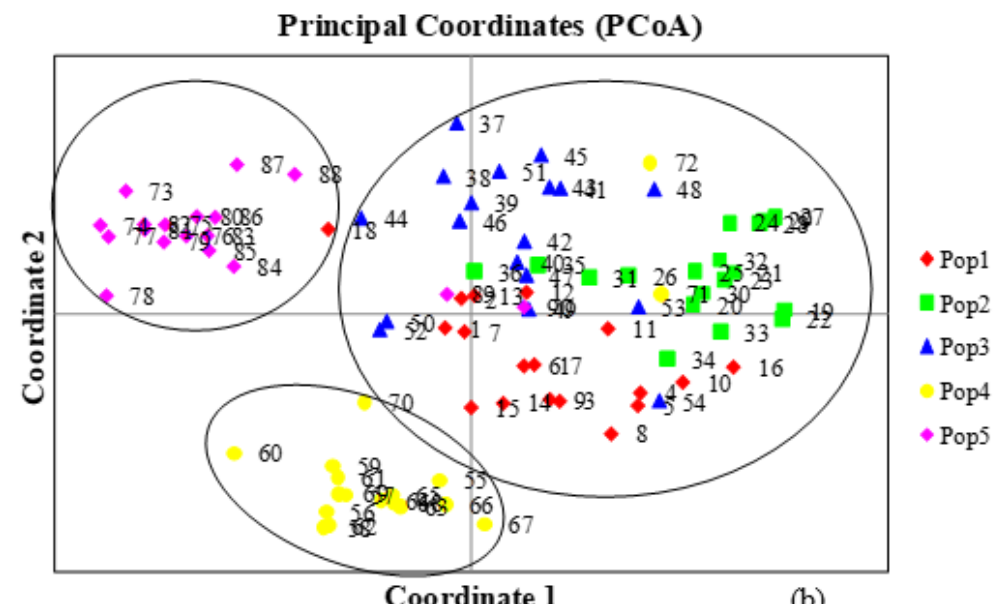

Fig. 3

\section{Figure 3}

a Unrooted genetic distance tree showing the relationships among five populations of P.cirrhifolium using RAPD marker [The tree was constructed by using a neighbor-joining method (Felsenstein, 2006). The numbers at the nodes of branches are the confidence values obtained from 1000 replications]

b Projection of 05 populations (90 individual) of P.cirrhifolium through PCA based genetic distance using RAPD marker. 1: Mukteshwar; P2: Pandavkholi; P3: Gagar; P4: Thanidar; P5: Satbunga 


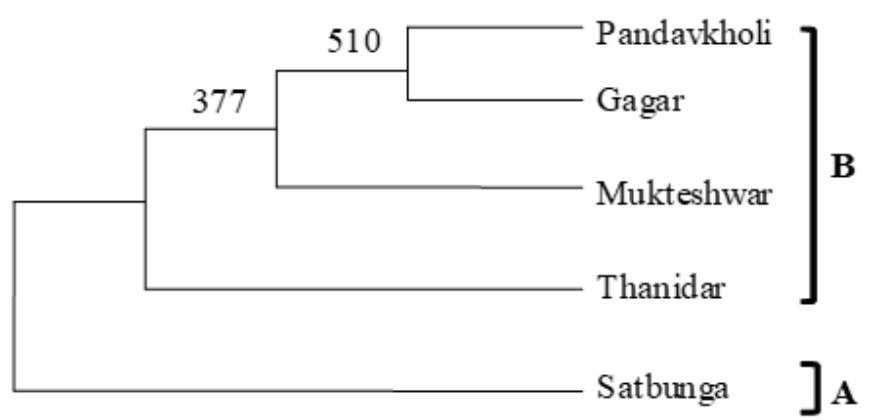

(a)

Principal Coordinates (PCoA)

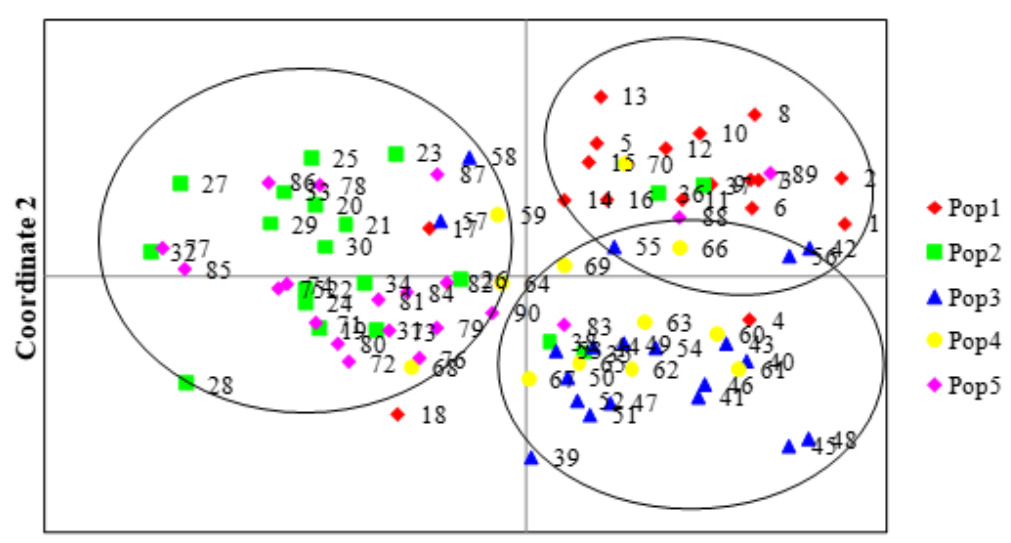

Coordinate 1

(b)

Fig. 4

Figure 4

a Unrooted genetic distance tree showing the relationships among five populations of P.cirrhifolium using ISSR marker [The tree was constructed by using a neighbor-joining method (Felsenstein, 2006). The numbers at the nodes of branches are the confidence values obtained from 1000 replications]

b Projection of 05 populations (90 individual) of P.cirrhifolium through PCA based genetic distance using ISSR marker. 1: Mukteshwar; P2: Pandavkholi; P3: Gagar; P4: Thanidar; P5: Satbunga 

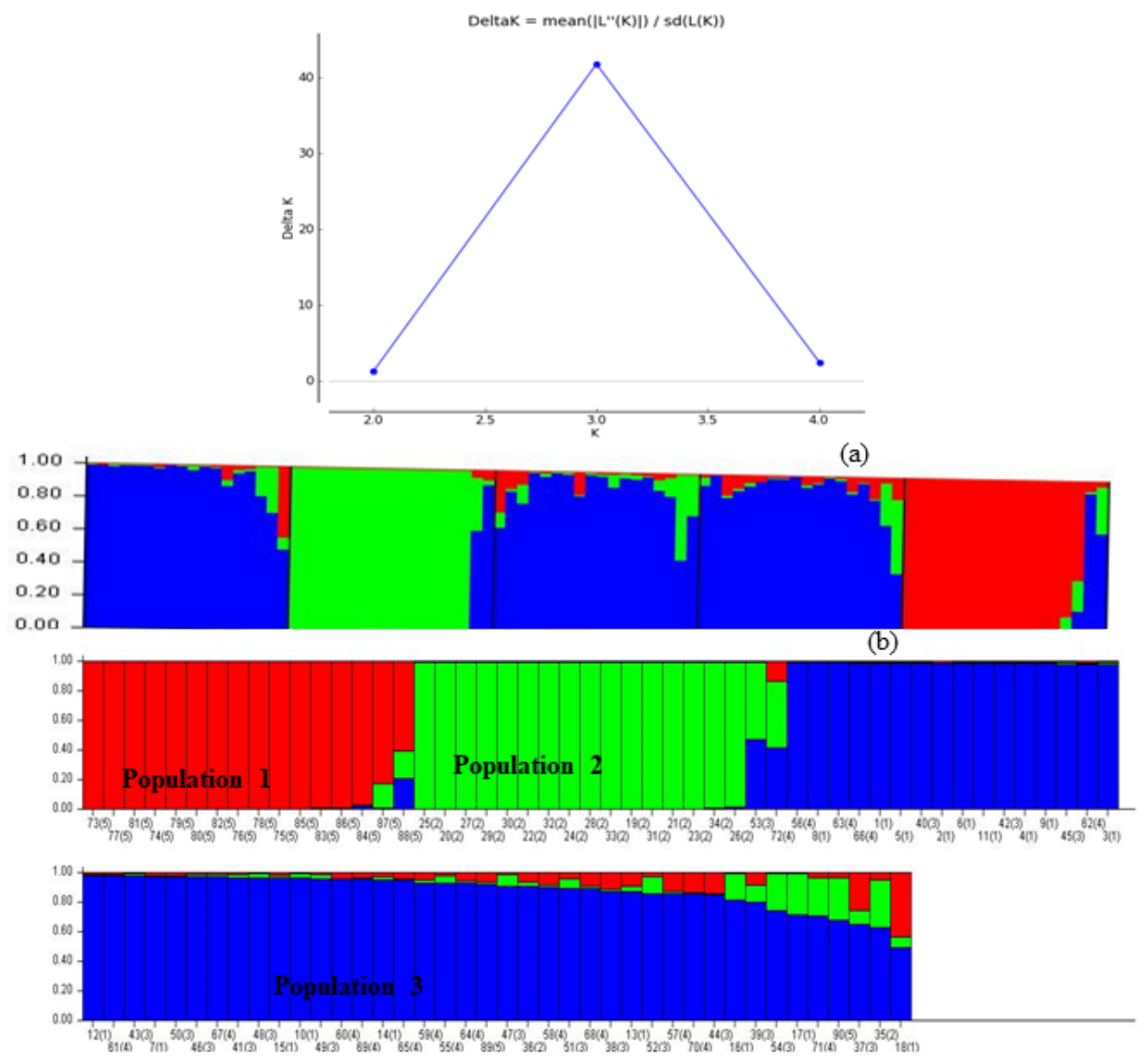

(c)

Fig.5

\section{Figure 5}

STRUCTURE analysis of natural populations of Polygonatum cirrifolium using combined inter-simple sequence repeat (ISSR) and Random amplified polymorphic DNA (RAPD) markers. (a) K=3 appeared to be the optimal number of clusters by showing the $\triangle \mathrm{K}$ at its peak; (b) Estimated genetic structure based on $\mathrm{K}=3$ using a Bayesian framework implemented in the STRUCTURE programme across 3 subpopulations of 165 individuals 

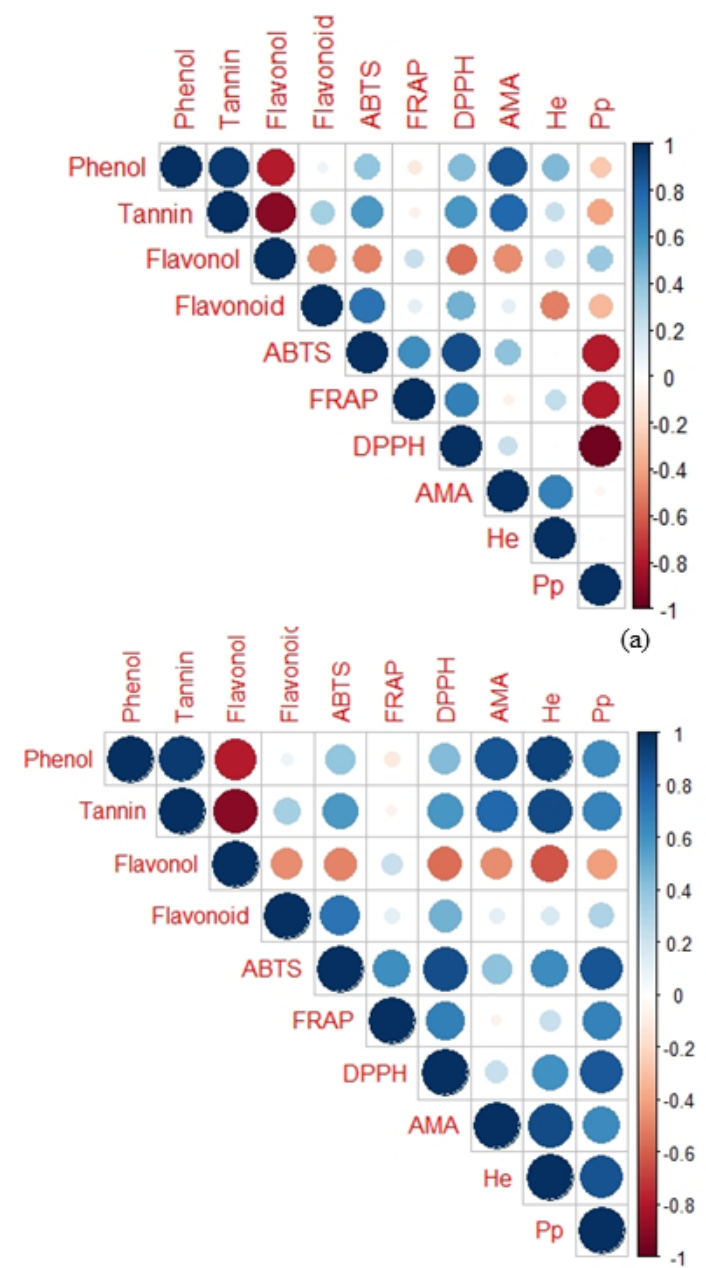

(b)

Fig.6

Figure 6

a Correlation analysis between phytochemicals, anti mutagenic activity and genetic diversity attributes analyzed through RAPD marker b Correlation analysis between phytochemicals, anti mutagenic activity and genetic diversity attributes analyzed through ISSR marker. ABTS- 2,2'-azino-bis(3-ethylbenzothiazoline-6-sulfonic acid; FRAP- ferric reducing antioxidant power assay; DPPH-2,2-diphenyl-1-picrylhydrazyl-hydrate; AMA- anti mutagenic activity, He- nei's genetic diversity ; Pp- percentage polymorphism 